\title{
COMPARTIMENTAÇÃO ESTRUTURAL DAS FORMAÇÕES PIRAMBÓIA E BOTUCATU NA REGIÃO DE SÃO JERÔNIMO DA SERRA, ESTADO DO PARANÁ
}

\author{
MICHAEL STRUGALE ${ }^{1}$, SIDNEI PIRES ROSTIROLLA ${ }^{2}$, FERNANDO MANCINI $^{2} \&$ \\ CARLOS VIEIRA PORTELA FILHO ${ }^{3}$
}

\begin{abstract}
STRUCTURAL FRAMEWORK OF PIRAMBÓIA AND BOTUCATU SANDSTONES IN THE REGION OF SÃO JERONNIMO DA SERRA-PARANÁ STATE - SOUTH BRAZIL The description and interpretation of the structural framework in the Pirambóia and Botucatu formations (São Bento Group - Mesozoic) of the intracratonic Paraná Basin is presented. The study area is located in Paraná State (South Brazil) which include the city of São Jerônimo da Serra. southeastern portion of the Paraná Intracratonic Basin. The stratigraphic sequence comprises aeolian porous quartz-sandstones and subordinate conglomerates and siltstones which constitute potential hydrocarbon and groundwater reservoirs, involving one of the most important recharge areas of the Guarani Aquifer System. In terms of the regional geological context, the area is located at the northeastern side of the Ponta Grossa Arch. specifically at the São Jerônimo - Curiúva magnetic lineament, which exhibits a notorious density of dolerite dykes and associated laulting system (atverage strike N45W). Field data, structural and 3D digital relief modeling and analysis and aerial photograph interpretation were used. The first-order structural feature is a conjugate fracture system described as: 1) normal to sinistral N.35-80W faults associated with zones of major lineament concentration, dykes and deformation bands; 2) secondary N50E dextral faults locally associated with deformation bands. Secondary E-W and N-S faults were also observed, which together with the first-order structural features promote an important compartmentation of the Guarani Aquifer and allow for the hydrocarbon migration in the Paraná Basin during the Late Cretaceous.
\end{abstract}

Kéyrords: Paraná Basin, structural geology, reservoir rock.

Resumo Este trabalho apresenta a descrição e interpretação) do registro estrutural das formações Pirambóia e Botucatu (Mesozóico - Grupo São Bento) numa porçãoo do flanco SE da Bacia do Paraná, região de São Jerônimo da Serra (Centro-norte do Estado do Paraná). Essa sucessão estratigrálica compreende quartzo-arenitos porosos, com conglomerados e siltitos subordinados, de ambiente deposicional predominantemente é́lico. Estas rochas fazem parte do Sistema Aquífero Guarani, situando-se dentro de uma das áreas de recarga deste, além de constituírem potenciais reservatórios de hidrocarbonetos. A área está contida no flanco nordeste do Arco de Ponta Grossa, mais especificamente no Alinhamento São Jerônimo-Curiúva, marcado por uma notável concentração de diques de diabásio e fallhas associadas. com direção média N45W. Os métodos empregados consistiram de levantamentos de campo, fotointerpretação, análise estrutural e de modelos digitais de terreno. A principal estruturação é dada por um sistema conjugado de fraturas: 1) falhas normais e sinistrais orientadas no intervalo N35-80W, onde se associam bandas de deformação e zonas com maior concentração de fotolineamentos e diques; 2) falhas dextrais orientadas N50E, de menor expressão em campo e aerofotografia. Foram observadas ainda fraturas secundárias E-W e N-S, que em conjunto com as fraturas N35-80W e N50E promovem uma importante compartimentação das rochas do Aquíferos Guarani, além de terem influenciado na migração de hidrocarbonetos na Bacia do Paraná durante o Eo-Cretáceo.

Palarras-chare: Bacia do Paraná, geologia estrutural, reservatório.

\begin{abstract}
INTRODUÇÃOO OSistema Aqüífero Guarani (SAG) (Araújo et al. 1995), que inclui as rochas psamíticas das Formações Pirambóia e Botucatu (Grupo São Bento da Bacia do Paraná), é um vasto reservatório subterrâneo de água na Bacia do Paraná. Estas unidades arenosas, na área de estudo, situam-se dentro de uma das zonas de recarga do SAG, em cotas altimétricas entre 900 e $1100 \mathrm{~m}$. Além disso, podem comportar-se como reservatório de hidrocarbonetos (HC) nas porções profundas da bacia, alimentado por falhas a partir de rochas geradoras nas formações Ponta Grossa (Grupo Paraná) e Irati (Grupo Passa Dois) devido ao aquecimento decorrente do aumento do grau geotérmico e do soterramento relacionados à Formação Serra Geral.
\end{abstract}

O objetivo deste trabalho é caracterizar as estruturas tectônicas regionais e locais presentes nas rochas do Grupo São Bento, em termos de disposição, morfologia e cinemática, de forma a compreender o arranjo destas estruturas e seus padrões regionais. cujo entendimento pode auxiliar na caracterização de zonas favoráveis a prospecção de água subterrânea e HC na Bacia do Paraná. São abordados, ainda, aspectos relacionados à estratigrafia das unidades mapeadas (Formações Rio do Rasto, Pirambóia, Botucatu e Serra Geral), bem como os aspectos morfoestruturais.

Os resultados foram obtidos da integração dos trabalhos de campo, interpretação de fotografias aéreas e análise de modelos digitais de terreno (MDTs). Em campo foram medidas atitudes

\footnotetext{
I - Petróleo Brasileiro S.A - UN-BA/ATEX/AAG. Av. Antônio Carlos Magalhães, 1113, 4"and, Itaigara. 41856-900 Salvador - BA. E-mail michacl_strugale (apetrobras.com.br

2 - Universidade Federal do Paraná, Setor de Ciências da Terra, Departamento de Geologia, Laboratório de Análise de Bacias e Petrofísica, Caixa Postal 19027 Centro Politécnico,81531-990) Curitiba - PR. E-mails: rostirolla@ufpr.br, ferman@geologia.ufpr.br

3. Petróleo Brasileiro S.A - UN-EXP/SOP/ABS/SAG. Av. Antônio Carlos Magalhães, 1113, 2ªnd, sl. 201. Itaigara, 4I856-90() Salvador - BA. E-mail: callino (a) petrobrats.com. br
} 
(notação $\mathrm{Clar}$ ) de fraturas e descritos seus aspectos geométricos, cinemáticos e de preenchimento. As medidas estruturais foram organizadas em uma planilha a partir da qual confeccionaram-se diagramas estruturais que mostram direção, mergulho, preenchimento e indicadores cinemáticos das fraturas. As fotografias aéreas (ITC-PR - escala 1:70.000 - ano 1962) foram interpretadas tendo como alvo as grandes zonas de falha, mergulhos das fraturas e camadas, resultando em um mapa fotogeológico. Foram ainda vetorizadas as curvas de nível de cartas topográficas (escala 1:50.000) para a construção dos MDTs, importantes na caracterização dos compartimentos de relevo, grandes falhas e demais morfoestruturas. As estruturas foram inicialmente abordadas na escala dos maiores padrões de falhamentos, dos quais observaram-se elementos da geometria, relaçôes temporais e arranjo espacial, revelando então o padrão de compartimentação estrutural regional. Em seguida foram tratados os dados de campo, através de diagramas e descrição das propriedades das fraturas, separando então os eventos tectônicos e seus respectivos produtos. A comparação e integração entre os dados estruturais obtidos em campo e através da fotointerpretação e MDTs permitiu a caracterização de dois eventos de deformação cujos registros aparecem nas rochas arenosas e ígneas (extrusivas e intrusivas) da área estudada, nas diferentes escalas de informação utilizadas.

\section{LOCALIZAÇÃOECONTEXTOGEOLÓGICOREGIONAL A} área de estudo situa-se na porção NE do Estado do Paraná, possuindo cerca de $990 \mathrm{~km}^{2}$ distribuídos nos municípios de Sapopema, Nova Santa Bárbara, Londrina, Tamarana e Ortigueira, além de São Jerônimo da Serra (Fig. 1), que situa-se no interior da área e oferece infra estrutura de hospedagem. O acesso é feito por estrada asfaltada (PR-09() - Rod. Do Cerne) a partir de Curitiba $(330 \mathrm{~km})$ ou Londrina $(85 \mathrm{~km})$. Da capital utiliza-se às rodovias BR-277/376 até Ponta Grossa, depois a PR-151 ate Piraí do Sul e PR-090, cruzando as cidades de Curiúva e Sapopema.

Dentre as diversas estruturas tectônicas de caráter regional presentes na Bacia do Paraná, a mais importante e proeminente é o Arco de Ponta Grossa, que é uma estrutura arqueada que merguIha suavemente para o interior da bacia, formando uma grande reentrância semi-elíptica que faz aflorar o embasamento (Cinturão Ribeira) na porção leste do Estado do Paraná e sul do Estado de São Paulo (Zalán et al. 1987). O arco foi reconhecido por Vieira (1973) e estudado em detalhe por Ferreira (1982), que utilizando dados aeromagnéticos definiu os grandes alinhamentos estruturais-magnéticos relacionados ao arqueamento de Ponta Grossa (Fig. 2).

A região estudada situa-se no contexto do Alinhamento São Jerônimo - Curiúva (Ferreira op. cit.), que constitui parte do flanco NE do Arco de Ponta Grossa. Em relação às faixas estruturais de Soares et al. (1982), localiza-se inteiramente na faixa MI-5 (Piraí do Sul - Curiúva), com direção $\mathrm{N} 45 \mathrm{~W} \pm 5$, e na continuidade da faixa PT-4 (direção N6()E \pm 5 ), faixa esta que coincide aproximadamente com a Zona de Falha Guaxupé de Zalán et al. (1987).

Na porção da Bacia do Paraná abordada neste trabalho afloram rochas dos grupos Passa Dois e São Bento (Fig. 3). O primeiro é composto por pelitos com intercalações de psamitos e localizadamente carbonatos, depositados em ambiente predominantemente marinho (exceto a Formação Rio do Rasto - continental), incluindo os folhelhos oleígenos da Formação Irati, principal rocha geradora de óleo na bacia. Já o Grupo São Bento é formado por uma sequiência clástica predominantemente arenosa com boa permeabilidade na base, representada pelas formações Pirambóia

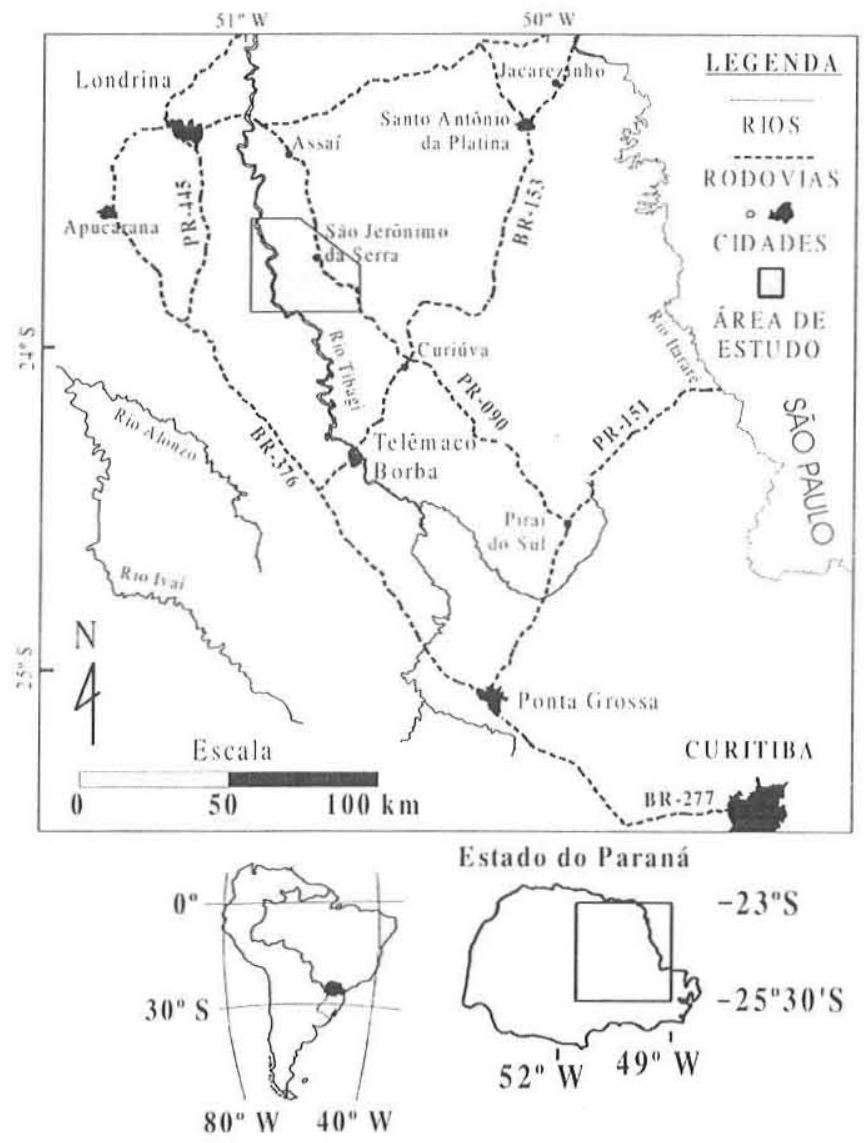

Figura I-Localização e acesso à área de estudo (Mod. DER-PR).

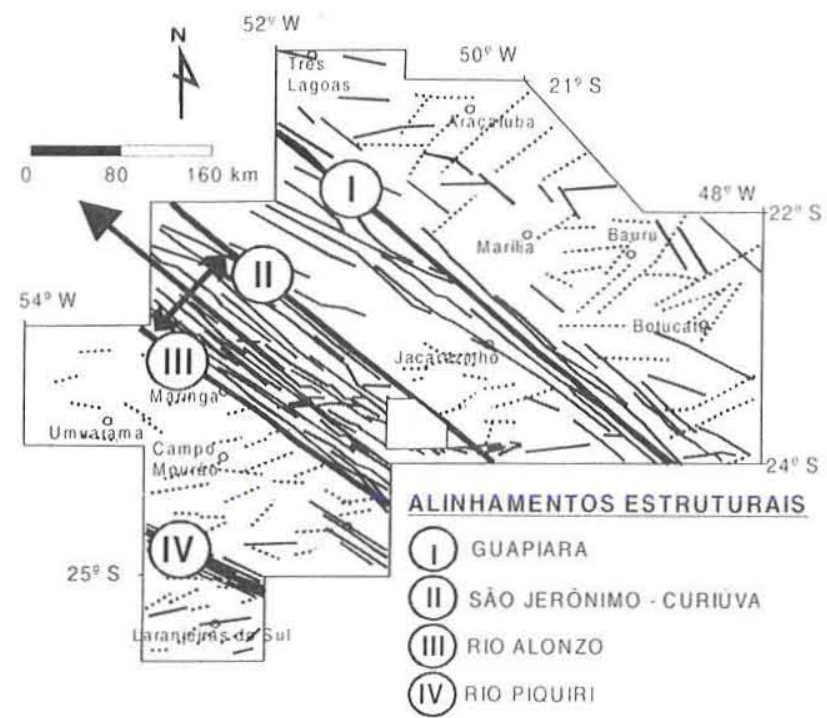

\section{LEGENDA}

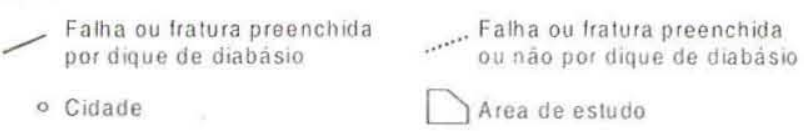

Figura 2 - Mapa com as principais estruturas magnéticas regionais da porşão Centro-leste da Bacia do Paraná (mod. Ferreira 1982). 


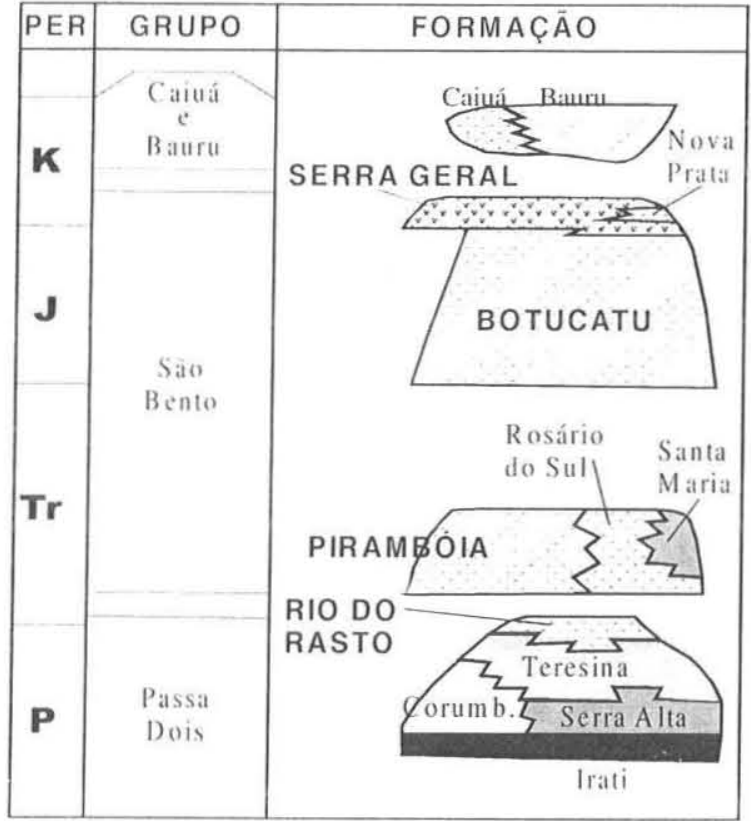

Figura 3 - Coluna estratigráfica parcial da Bacia do Paraná (mod. de Milani et al. 1994. França e Potter 1998 e Fernandes \& Coimbra 2000).

c Botucatu. enquanto no topo ocorrem espessas rochas extrusivas básicials (localmente intermediárias e ácidas) da Formação Serra Geral, além das intrusivas de composição semelhante, na forma de diques e sills, correlacionáveis à esta unidade.

\begin{abstract}
ARCABOUÇO ESTRATIGRÁFICO Nárea de estudo foram identificadas as seguintes formações: Rio do Rasto: (Permiano Superior a Triássico Inferior), posicionada no topo do Grupo Passa Dois: Pirambóia (Triássico), Botucatu e Serra Geral, estas três inclusas no Grupo São Bento (França \& Potter 1988. Milani et al. 1994). O arranjo espacial destas unidades é apresentado no mapa geológico da figura 4.
\end{abstract}

Formação Rio do Rasto Esta unidade aflora nos baixos topográficos da figura 4 (porções central, nordeste e sudeste) principalmente na região dos vales dos rios do Tigre e Água do Capim. Caracteriza-se por siltitos vermelhos a roxos (esverdeados quando alterados), laminados e com aspecto pastilhado, e camadas tabulares de arenitos com até $2 \mathrm{~m}$ de espessura, que são brancos a avermelhados, finos a muito finos, lamosos, mal-selecionados, com estratilicação cruzada tabular e acanalada de pequeno porte (sês de até 6() $\mathrm{cm}$ ) ou mesmo aspecto maciço. A passagem para o siltito, tanto na base como no topo, costuma se dar de forma abrupta.

Formação Pirambóia A Formação Pirambóia assenta-se por discordância litológica com suave angularidade sobre a Formação Rio do Rasto (Soares 1973, 1975), marcada por sutil truncamento de camadas Rio do Rasto sob a Formação Pirambóia, configurando uma feição tipo toplap (Strugale 2002). É constituída de litologias quase exclusivamente arenosas, friáveis, num pacote de até $20 \mathrm{~m}$ de espessura que apresenta reduzida quantidade de afloramentos. Predominam arenitos muito-finos a finos, siltosos, brancos, com seleção regular e estratificações cruzadas acanaladas de baixo ângulo e sigmoidas (sets entre l e $3 \mathrm{~m}$ ), além de estratificações e laminações plano-paralelas. No topo foi constatada a presença de bolas de argila plástica arroxeada, com diâmetro médio ao redor de $10 \mathrm{~cm}$; nas superfícies de reativação observam-se lâminas mili a centimétricas de siltitos verdes. Os litotipos e geometria dos estratos da Formação Pirambóia na região estudada, sugerem um ambiente deposicional de lençóis de dunas eólicas com interdunas úmidas localmente intercaladas com depósitos fluviais, semelhantes ao ambiente descrito por Caetano-Chang (1993).

Formação Botucatu A maior espessura da Formação Botucatu na região estudada corresponde a arenitos vermelhos, quartzosos, finos, seleção em geral boa (bimodal), grãos arredondados e com pouca argila na matriz, com espessura de até $50 \mathrm{~m}$. Apresentam estratificação cruzada acanalada de médio a grande porte ( $s e t s$ de até $10 \mathrm{~m}$ de altura), sendo indicativo de sedimentação em ambiente desértico, na forma de grandes ergs. Este pacote superior será, neste trabalho, tratada como Fácies Eólica. Em afloramentos na área de estudo e regiões adjacentes (Serra do Cadeado e Rio Branco do Ivaí - PR) ocorre um pacote com até $20 \mathrm{~m}$ de espessura na seção basal da Formação Botucatu, composta por arenitos médios a grossos, as vezes conglomeráticos, quartzosos, amarelos ou vermelhos, com estratificações cruzadas acanalada e tabular e de pequeno porte e bolas de argila nas superfícies de reativação, além de raros pacotes rítmicos de siltitos argilosos vermelhos. Sugere-se um ambiente deposicional fluvial tipo entrelaçado (braided) em clima árido, resultado de fluxos esporádicos de água, e eventuais planícies de inundação com lagos efêmeros. Esta fácies corresponde à Fácies Torrencial de Soares (1973) posicionada na base da Formação Botucatu, denominação que será mantida neste texto. O contato desta fácies com a Formação Pirambóia se dá na forma de discordância angular, a qual é uma superfície ondulada com formas de preenchimento de canal, sucedida por cerca de $40 \mathrm{~cm}$ de uma brecha de matriz arenosa com bolas de siltito-argiloso verde e marrom, grânulos e seixos de quartzo, além de laminações convolutas,

Formação Serra Geral Ocupando o topo da coluna estratigráfica na região estudada, a Formação Serra Geral é representada por basaltos e alguns estratos de dacitos porfiríticos resultantes de vulcanismo fissural. Os basaltos são negros, afaníticos ou equigranulares muito finos; quando alterados apresentam cor cinza e esfoliação esferoidal, o que permite seu aproveitamento como saibro. Já os dacitos porfiríticos possuem matriz afanítica de cor cinza escuro com fenocristais subédricos milimétricos (eventualmente centimétricos) de plagioclásio, além de serem mais resistentes à erosão do que os basaltos, talvez em função de seu aspecto menos fraturado. É comum a ocorrência de camadas de arenitos eólicos intercaladas aos basaltos, denominadas arenitos intertrapp (Maack 1967), as quais atestam o caráter de continuidade da "sedimentação Botucatu" durante o "vulcanismo Serra Geral" e assim sua estreita relação temporal. Na Região da Serra do Cadeado (PR) afloram três níveis de arenitos intertrapp, onde um destes apresenta até $20 \mathrm{~m}$ de espessura. Nota-se ainda um expressivo conjunto de corpos intrusivos colocados durante o magmatismo Serra Geral, representados na forma de diques e soleiras de rochas básicas e alguns diques félsicos. Os diques são as feições mais representativas devido à sua expressão no relevo, representados por altos topográficos alinhados segundo N40-50W, que podem ser bastante expressivos nas rochas pelíticas das unidades 


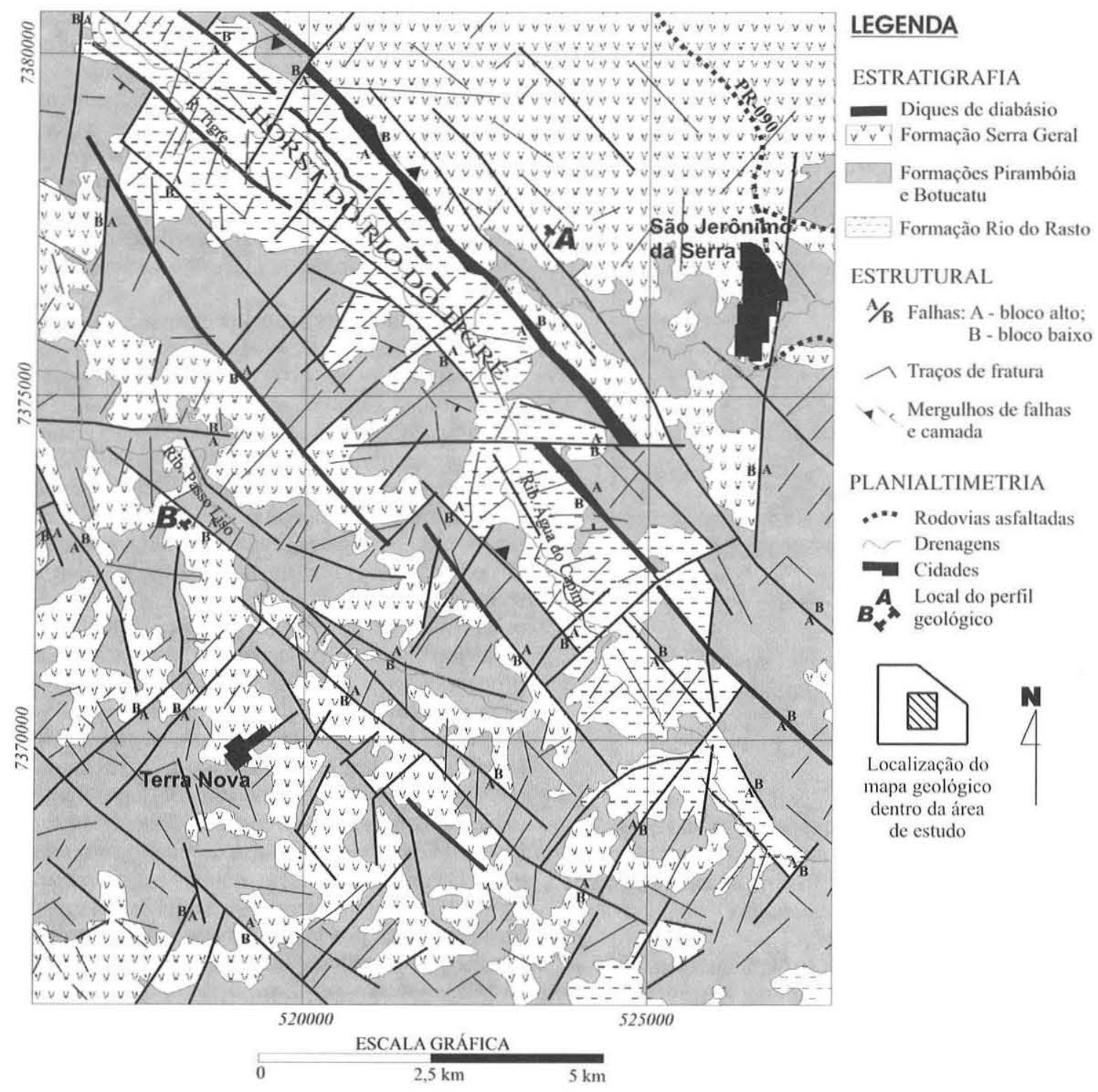

Figura 4 - Mapa fotogeológico da Região de São Jerônimo da Serra (PR), detalhando a parte central da área de estudo.

permianas. Já nas rochas psamíticas do Grupo São Bento os diques em geral ocorrem em vales alinhados na mesma direção, exceto aqueles associados a grandes escarpas de falha, como no caso da borda nordeste do Horst Rio do Tigre. Alguns diques, em função de suas maiores dimensões, apresentam rochas máficas e secundariamente félsicas de granulação média a grossa. Na porção sudeste da Zona de Falha Serra Grande, observou-se três diques com até $100 \mathrm{~m}$ de largura, compostos de rocha félsica com fenocristais de plagioclásio (até $1 \mathrm{~cm}$ ) e matriz equigranular fina a média; secundariamente, ocorrem derrames com textura traquítica e de fenocristais de plagioclásio de até $1,5 \mathrm{~cm}$ em matriz afanítica. A maior resistência destes diques à erosão é evidenciada por serras e picos alinhados segundo N45W junto ao Rio Tibagi (Serra Grande e Chata, Morro do Paredão e o Pico Agudo), elevando-se até $7(0) \mathrm{m}$ em relação a seu leito. Estes diques assemelham-se àqueles descritos no Escudo Paranaense por Marini et al. 1967 como constituídos de diorito pórfiro, quartzo-dioritos ou dacitos.
ASPECTOS MORFOESTRUTURAIS As morfoestruturas da área estudada são controladas: (1) pela unidade litológica aflorante (resistência a erosão) e (2) pelas estruturas tectônicas (fraturas e diques). A Formação Rio do Rasto, essencialmente pelítica, ocupa os baixos topográficos em razão de sua menor resistência a erosão em relação às unidades psamíticas sobrepostas (formações Pirambóia e Botucatu). A Formação Serra Geral ocupa o topo da coluna estratigráfica na região e suas litologias também são menos resistentes ao intemperismo em comparação aos arenitos, formando então colinas aplainadas de encostas convexas, onde nos vales principais por vezes afloram arenitos da Formação Botucatu. As formações Pirambóia e Botucatu geralmente afloram em taludes íngremes, especialmente a segunda, onde a Fácies Torrencial forma escarpas contínuas de até $20 \mathrm{~m}$ de altura, e a Fácies Eólica sustenta escarpas de até $50 \mathrm{~m}$ de altura restritas às escarpas de falhas. Os controles morfoestruturais por estruturas tectônicas são importantes, visto que a localização dos vales é em parte con- 
trolada por estruturas que aceleram o intemperismo, e altos topográficos devem-se a diques de diábasio ou rochas silicificadas. O controle mais importante, tanto dos altos quanto baixos topográficos, resulta de estruturas de direção N40-50W (figs. 5, 6 e 7), em geral ocupadas por diques que podem atingir até uma centena de metros de largura. Como exemplo, o aqui denominado Horst do Rio do Tigre (HRT), se caracteriza por um alto estrutural assimétrico onde as camadas dentro da estrutura mergulham preferencialmente para SW. É balizado por grandes falhas com mergulhos para NE, aliados aos mergulhos divergentes das camadas nas adjacências da estrutura (Fig. 5). O HRT situa-se nos domínios da Zona de Falha Rio do Tigre (Fig. 7), e os MDTs da figura 6 mostram o HRT como um baixo topográfico alinhado segundo $\mathrm{N} 45 \mathrm{~W}$, limitado por um par de altos topográficos. Na figura 6a observa-se uma forte tendência da diminuição das cotas para o quadrante NW, que deve estar relacionado ao mergulho regional das camadas. Os demais aspectos estruturais serão descritos oportunamente.

As fraturas de direção média N50-60E exercem controles localizados, em razão de sua menor persistência e continuidade em relação às estruturas $\mathrm{N} 40-50 \mathrm{~W}$, exceto quando sofreram reativação posterior a implantação destas. Já as fraturas de direção E-W exercem um controle sutil na topografia, através de alinhamentos separados entre si por distâncias entre 4 e 6 km que separam compartimentos mais e menos elevados (Fig. 6a). As fraturas de direção $\mathrm{N}$-S exercem controles morfoestruturais localizados.

ARCABOUÇOESTRUTURAL A descrição, mediçãoe interpretação das estruturas rúpteis e feições tectônicas associadas foram efetuadas nas diversas escalas disponíveis, tendo como partida mapas regionais da Bacia do Paraná (Ferreira 1982, Soares et al. 1982, Zalán et al. 1987) onde são mostradas feições estrutu- rais e magnéticas com dimensões de dezenas a centenas de quilômetros (Fig. 2). A interpretação das fotografias aéreas na escala 1:70.000 e MDTs da área de estudo e dos arredores, permitiu identificar as principais direções das feições lineares e as zonas mais estruturadas, bem como a continuidade e persistência destas estruturas (Fig. 7). Em escala de afloramento, foram descritas estruturas planares e lineares, tais como juntas, falhas, estrias, degraus (steps), dentre outros indicadores cinemáticos. No caso de juntas e falhas, foram observados aspectos como morfologia, material de preenchimento, relações temporais entre as famílias, espaçamento e estruturas planares indicativas de movimentação, bem como feições de cisalhamento, principalmente bandas de deformação. Sempre que possível, as juntas e falhas foram agrupadas em sistemas ou famílias ainda no campo.

Fotolineamentos O conjunto dos mapas regionais mostra uma compartimentação romboédrica na porção centro-leste da Bacia do Paraná, balizada por estruturas N40-60W e N50-70E, além de esporádicas estruturas E-W. Este padrão se mantém quando observadas as duas principais direções estruturais do mapa de fotolineamentos (Fig. 7), onde estão ainda plotados os diagramas de rosetas e contornos dos pólos das fraturas medidas em campo. A fotointerpretação permitiu a identificação de quatro zonas retilíneas mais estruturadas, de direção N40-50W, relacionadas ao Alinhamento São Jerônimo-Curiúva. Neste trabalho foram denominadas, de nordeste para sudoeste: Zona de Falha (ZF) Rio do Tigre, ZF Apucaraninha, ZF Serra Grande e ZF Tamarana (Fig. 7). Se tratam de zonas lineares com largura média de $3 \mathrm{~km}$ (exceto a ZF Tamarana, com até $8 \mathrm{~km}$ ), onde concentração e continuidade dos feixes de alinhamentos estruturais e diques de diabásio de direção N40-50W é significativamente maior. Associam-se ainda a baixos
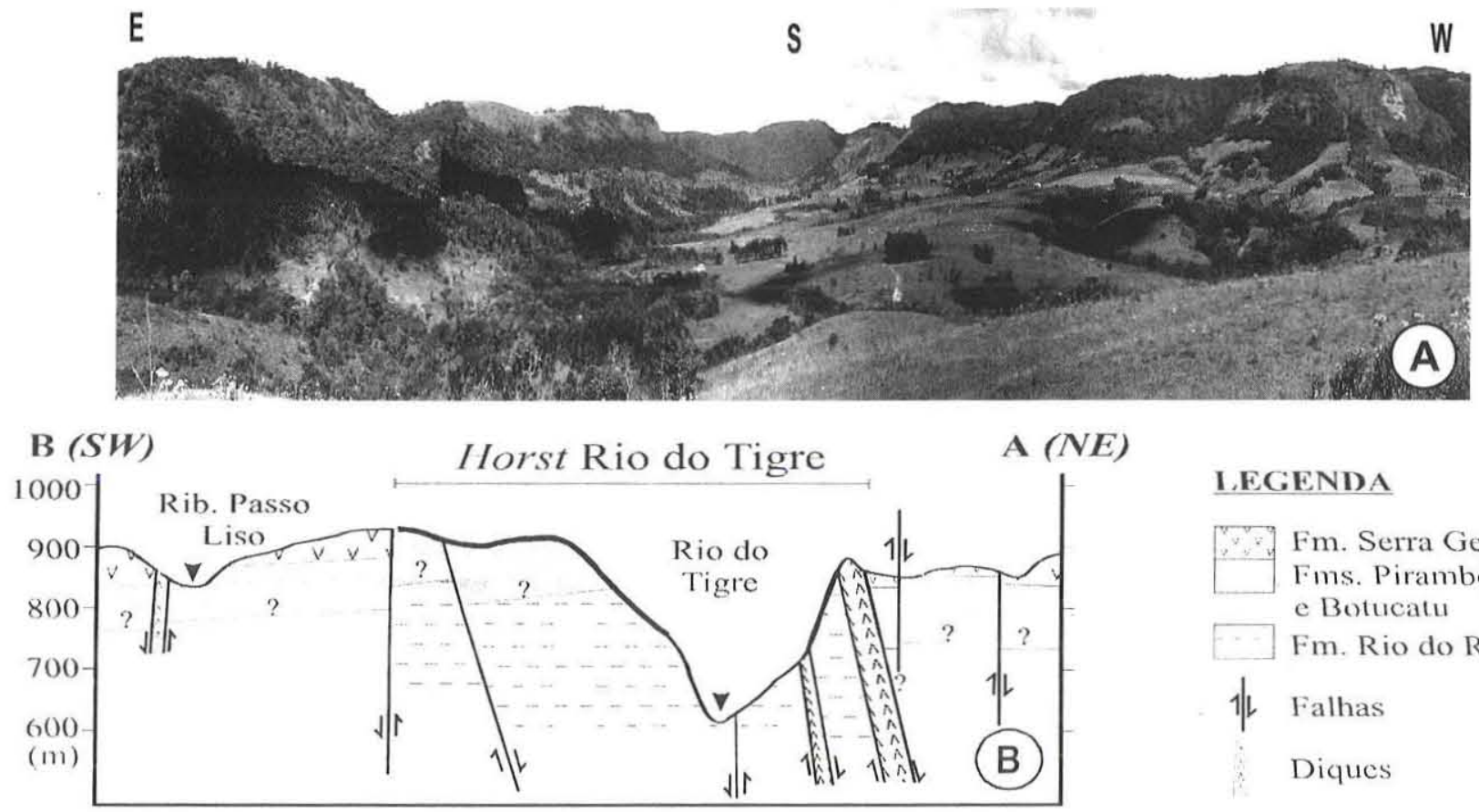

Figura 5 - Horst Rio do Tigre (HRT), onde: A) fotomosaico no local aproximado do perfil geológico; B) perfil geológico do HRT, mostrando o estilo estrutural, as unidades litoestratigráficas e as principais falhas (localização do perfil: ver mapa geológico da fig. 4). 

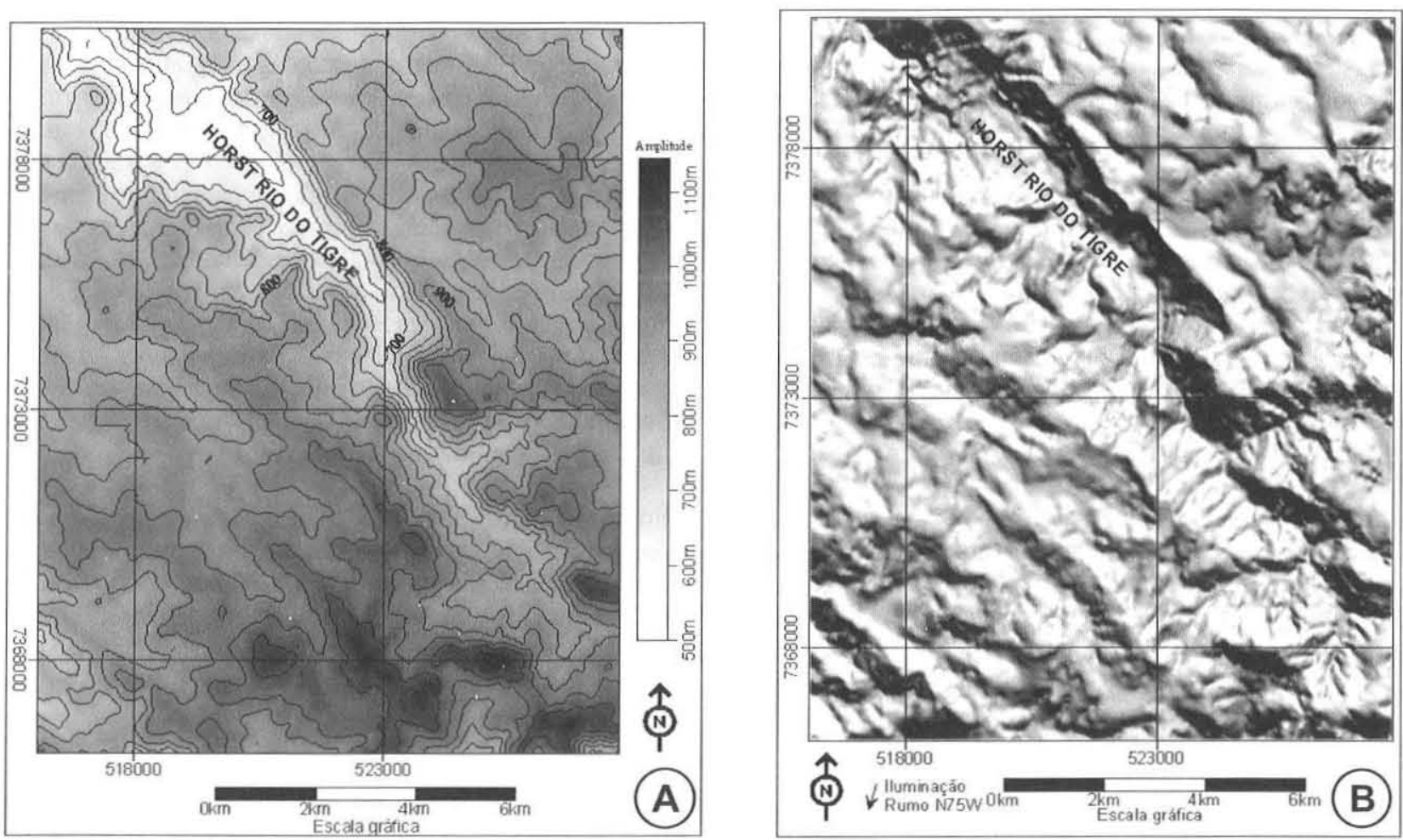

Figura 6 - Modelos digitais de terreno da região de São Jerônimo da Serra, onde: A) MDT hipsométrico onde a escala de cores indica a elevação em metros; B) MDT tipo relevo sombreado, que evidencia a estruturação N40-50W.

topográficos e a uma maior descontinuidade das demais direções estruturais, especialmente a N40-60)E. Estas zonas de falhas separaram porções onde os alinhamentos N40-50W são menos conspícuos, o que permitiu observar melhor das falhas N40-60E nas aerofotografias.

DIREÇÃO N40-50W A direção N40-50W caracteriza-se por alinhamentos retos ou curvilíneos, bastante contínuos e distribuídos por toda a área, apresentando maior densidade nas zonas de falha (Fig. 7). No interior destas, ocorrem porções onde os alinhamentos estruturais apresentam geometria anastomosada que por vezes indicam uma cinemática dextral.

DIREÇÃO N40-60E É o segundo trend estrutural mais importante da região, como observado no diagrama de freqüência acumulada dos fotolineamentos (Fig. 7). São alinhamentos descontínuos no comprimento, mas com alta frequiência e quase sempre segmentados pelos alinhamentos principais (N40-50W). Observam-se duas zonas mais estruturadas na figura 7: 1) setores sudeste e sul, com direção média N50-55E; 2) no quadrante NW, com as estruturas na direção N40E. Em MDT de escala regional, a primeira faixa apresenta geometria anastomosada e a segunda é retilínca. Em alguns locais, alinhamentos de direção N40-60E segmentam alinhamentos $\mathrm{N} 4()-50 \mathrm{~W}$, especialmente nas regiões entre as zonas de fallhas.

DIREÇÕES E-W eN-S Os lineamentos de direção E-W apresentam-se como zonas estreitas de traços contínuos, porém bem espaçadas entre si $(6 \mathrm{~km}$ em média) que denotam caráter de superposição em relação às demais direções de fotolineamentos.
Foram observados diques de diabásio deslocados e relevo suavemente escalonado por falhas desta direção. Já os lineamentos N-S caracterizam-se por traços mais descontínuos e segmentados em comparação à direção E-W. Concentram-se na porção leste e na região do vale do Rio Tibagi, cujo curso tem a mesma orientação N-S (Fig. 7).

Dados de Campo JUNTAS As juntas são as estruturas com maior número de medidas obtidas em campo, às quais foram agrupadas em diagrama sinóptico (Fig. 7). Foram descritas juntas preenchidas por carbonato euédrico e fibroso, óxidos de manganês e ferro. Quanto à geometria, relacionada à rugosidade, as juntas foram dividas em planas, onduladas/anastomosadas e irregulares: 1) as juntas planas têm direções predominantes N6()-7()E e N20$30 \mathrm{~W}$ e subordinadamente N75W-EW e N50-60W; 2) as juntas anastomosadas e onduladas concentram-se entre N70E-EW e N70W-EW, além de um máximo em N30-50E (mergulho para NW) para as juntas onduladas; 3 ) as irregulares possuem máximo em N30-45W (mergulho para NE), com uma pequena concentração em N80W.

Os diagramas da figura 8 mostram as direções e mergulhos das juntas em cada uma das unidades mapeadas. Em função do menor número de medidas nos arenitos friáveis da Formação Pirambóia, são representativos apenas os diagramas das formações Botucatu e Serra Geral. Nestas unidades observa-se alguma alteração no padrão de deformação, contribuindo no aspecto da compreensão de particularidades nos registros estruturais em cada um dos litotipos (arenitos e rochas básicas). Entretanto, a variação nas direções principais das fraturas pode refletir apenas uma diferença nas propriedades reológicas e estruturas herdadas de cada litotipo, 

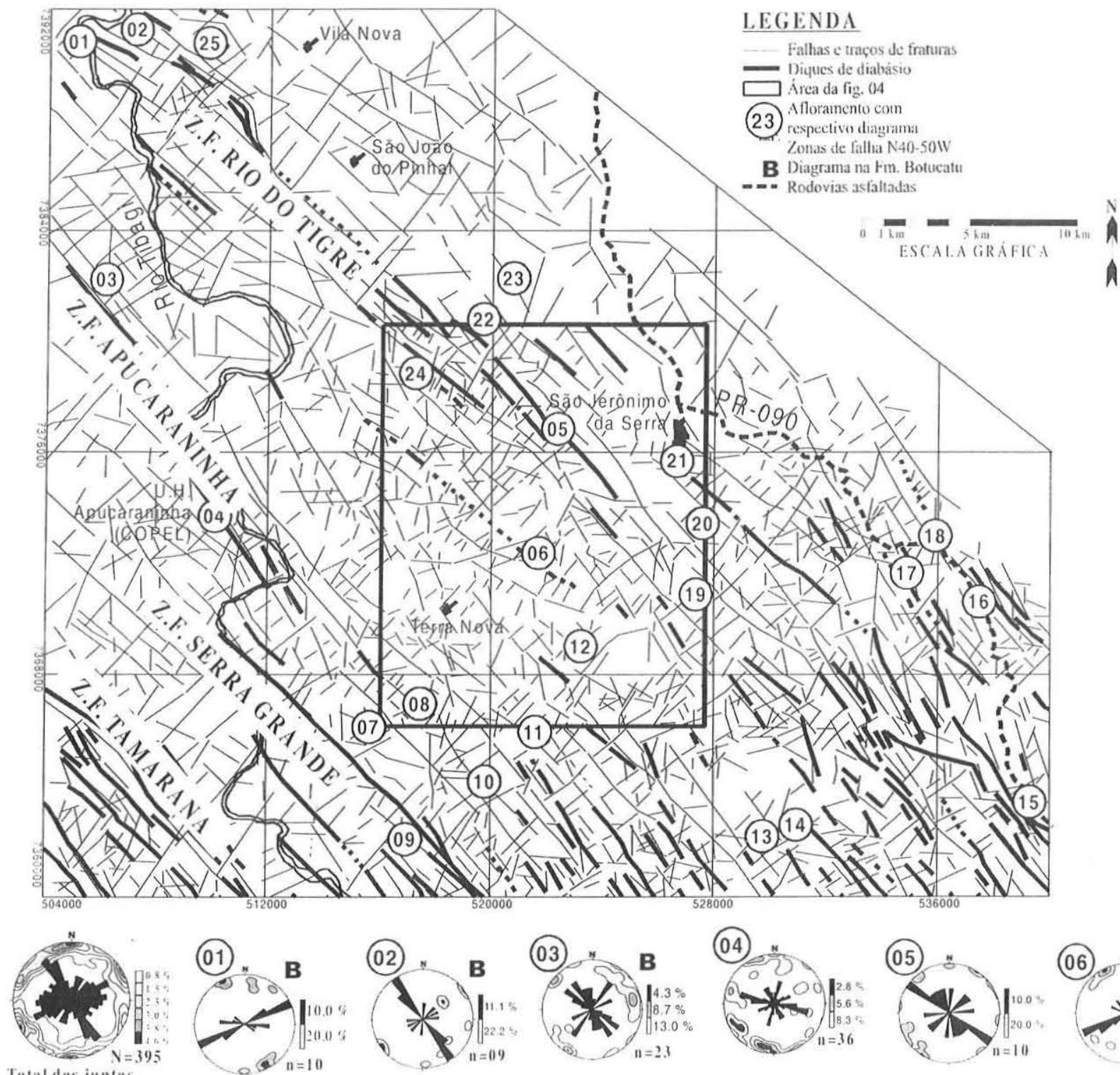

(03)"
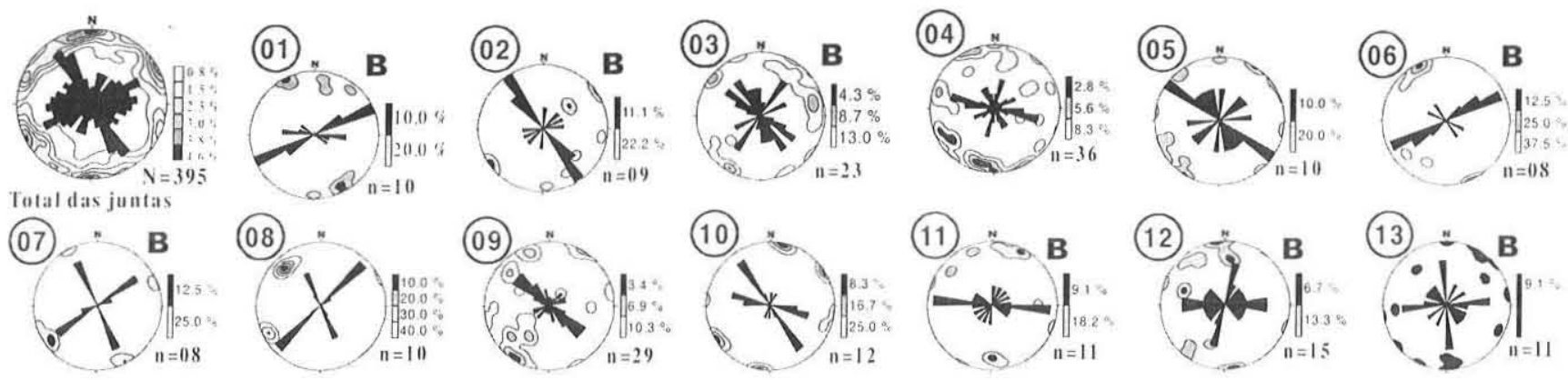

(11). B

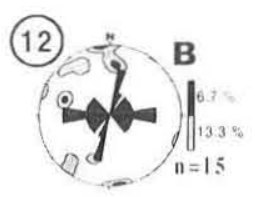

(13) $\because \mathbf{B}$
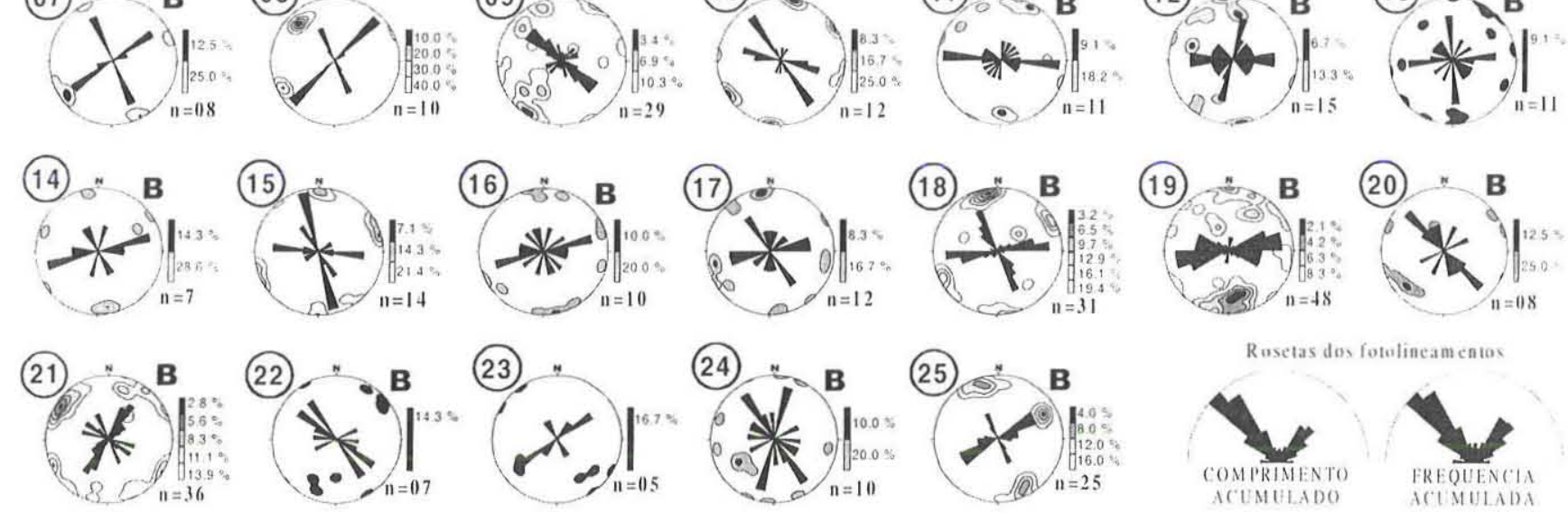

Figura 7 - Fotolineamentos extraídos de fotografias aéreas 1:70000, e diagramas dos contornos dos pólos e rosetas das fraturas nos pontos de campo e sinóptico das juntas. 
fato observado em campo, onde os arenitos bem litificados da Formação Botucatu mostram melhor os fraturamentos em comparação aos arenitos friáveis da Formação Pirambóia. As fraturas nos diques e derrames da Formação Serra Geral foram analisadas tanto em conjunto quanto separadamente (Fig. 8d, 8e e 8f).

Na Formação Pirambóia (Fig. 8a) a única direção consistente situa-se entre N30-70W e não foi determinante na análise estrutural, pois o diagrama foi confeccionado a partir de apenas dois pontos de campo. O registro das juntas na Fácies Torrencial (Formação Botucatu, fig. 8b) tem direção principal N70E-EW, com máximos secundários N35W, N75W, N55W e N35E, mostrando uma dispersão maior que a Fácies Eólica, talvez em razão da maior heterogeneidade litológica. Esta última (Fig. 8c) mostra dois máximos, N40W e N50E, que geometricamente indicam um par conjugado, além de um máximo secundário E-W semelhante aos da Fácies Torrencial. No diagrama integrado da Formação Serra Geral (Fig. 8d), as principais direções são N45E (mergulho para SE) e N2()-50W com mergulho em geral para NE, além do intervalo N80W a EW. A análise dos diagramas de diques e derrames em separado sugere que houve uma rotação nas direções de fraturas (partição da deformação), pois as concentrações de pólos em cada diagrama (figs. 8e, 8f) se repetem no diagrama sinóptico (Fig. 8d). A observação dos dados da figura 8 indica diferenças nos registros deformacionais para arenitos e rochas básicas, exceto para a direção $\mathrm{E}-\mathrm{W}$, a qual é onipresente nos diagramas.

FALHAS E FEIÇÕES LINEARES A associação entre falhas e indicadores cinemáticos lineares é direta, mas não condicional na determinação da cinemática, uma vez que se observaram feições não lineares que também são indicativas de fraturas com desloca- mento, tais como bandas de deformação e feições sigmóides (interseção das direções "Y" "e "P" de Riedel) associadas a planos de falha anastomosados. As principais falhas medidas em campo são reunidas em diagramas sinópticos na figura 9. As feições cinemáticas descritas são sulcos, estrias (às vezes com ressaltos steps), fraturas escalonadas e juntas plumosas. Os arenitos são pobres em feições lineares, predominando indicadores cinemáticos como fraturas escalonadas (intercessão dos planos R e R' com a direção Y), sigmóides, sulcos e juntas plumosas. A presença dos diques de diábasio é indicativa de movimentação gravitacional, produto do episódio distensional que permitiu o encaixe destes, e corroborada com rejeitos normais associados às principais falhas $\mathrm{N} 40-65 \mathrm{~W}$ do perfil da figura 05 .

A forma de cristalização dos minerais que preenchem a falhas, em especial os carbonatos, pode indicar que as mesmas estavam sob compressão ou distensão. Como exemplo, na figura 10a observa-se uma falha preenchida por calcita euédrica que continha sulcos sub horizontais em uma das paredes, evidenciando dois episódios de 'esforços (distensivo e cisalhante) na falha. No mesmo local, a outra família de falhas apresentava estrias em carbonato fibroso (Fig. 10b).

As feições de cisalhamento mais abundantes nos arenitos são as bandas de deformação, constituídas de planos de fraturas típicas de arenitos porosos, tal como observado nas formações Pirambóia e Botucatu, onde o cisalhamento é acomodado por colapso da porosidade, fraturamento (escala de grão), redução da granulometria por cominuição e fluxo cataclástico conforme o modelo de Aydin (1978 apud Davis et al. 1999). Magnavita (200)) relacionou o fluxo de fluídos com o estágio de desenvolvimento das bandas em reservatórios da Bacia do Recôncavo; resumida-

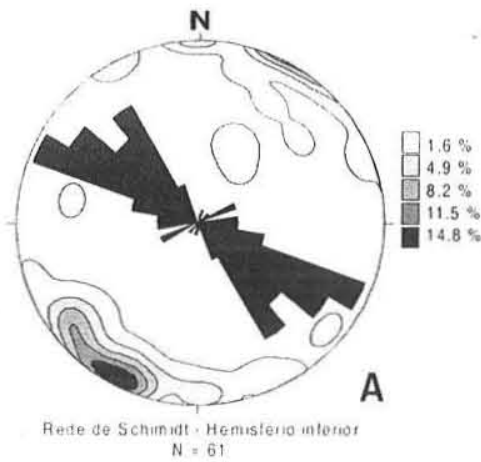

N

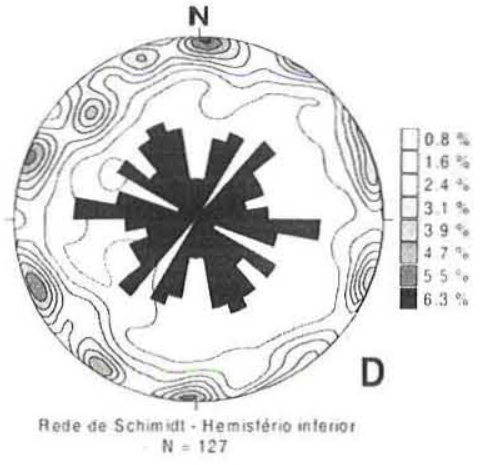

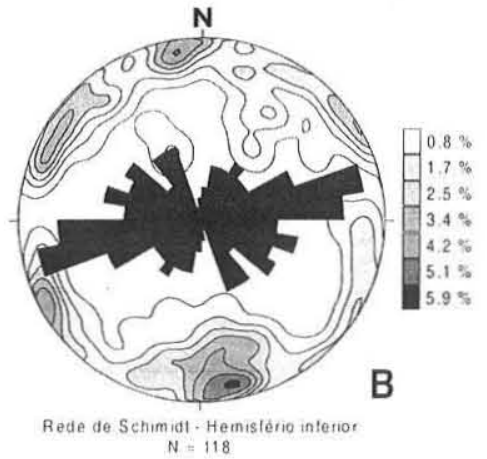

N

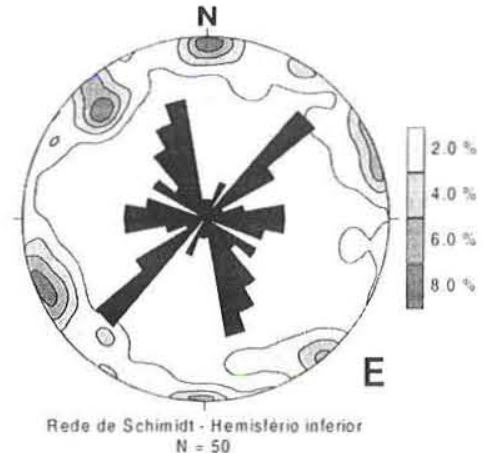

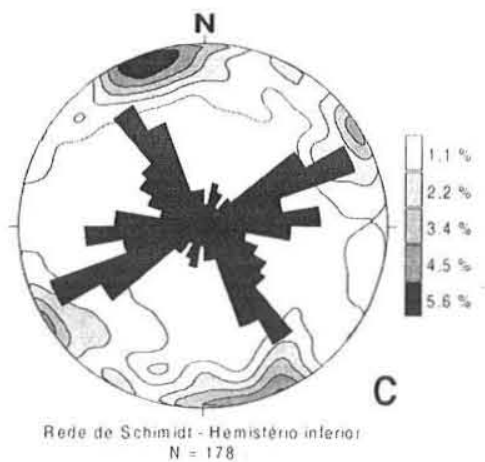

$\mathrm{N}$

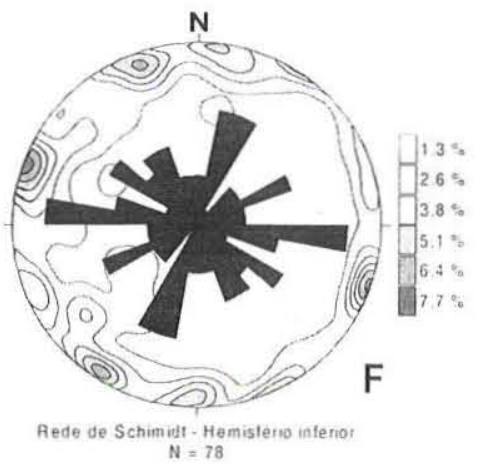

Figura 8- Diagramas de contornos e rosetas das juntas medidas nos afloramentos do Grupo São Bento: A) Formação Pirambóia; B) Formação Botucatu (Fácies Torrencial); C) Formação Botucatu (Fácies Eólica); D) Formação Serra Geral (sinóptico); E) Diques de diabásio da Formação Serra Geral; F) Derrames da Formação Serra Geral. 
mente, as bandas são importantes zonas de convergência de fluídos durante a movimentação da falha, mesmo quanto posicionadas em rochas de alta porosidade. Com o término do deslocamento, a precipitação dos minerais carreados através da zona de falha impermeabiliza a fratura, que passa a atuar como barreira $\mathrm{e}$, ao mesmo tempo, empresta à suas paredes a propriedade de concentrar o fluxo de fluídos. Da mesma forma, nota-se que estas estruturas, principalmente na Formação Botucatu, são silicificadas (mais resistentes ao intemperismo), em geral

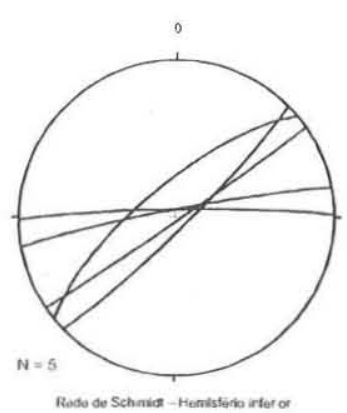

(A) Falhas dextrais

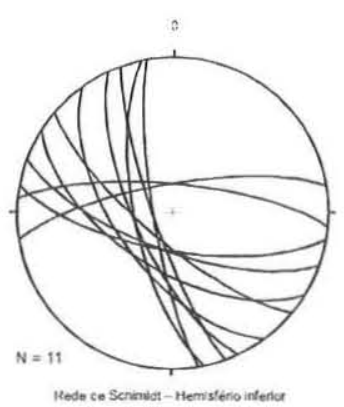

(B) Falhas sinistrais

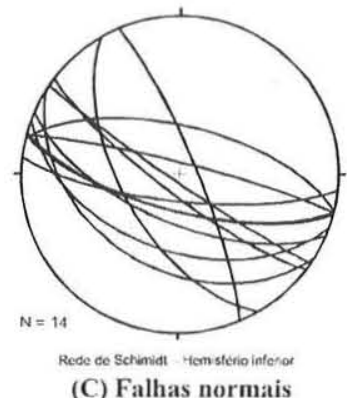

(C) Falhas normais

Figura 9 - Estereogramas das falhas da região de São Jerônimo da Serra: A) falhas dextrais; B) falhas sinistrais; C) falhas normais.

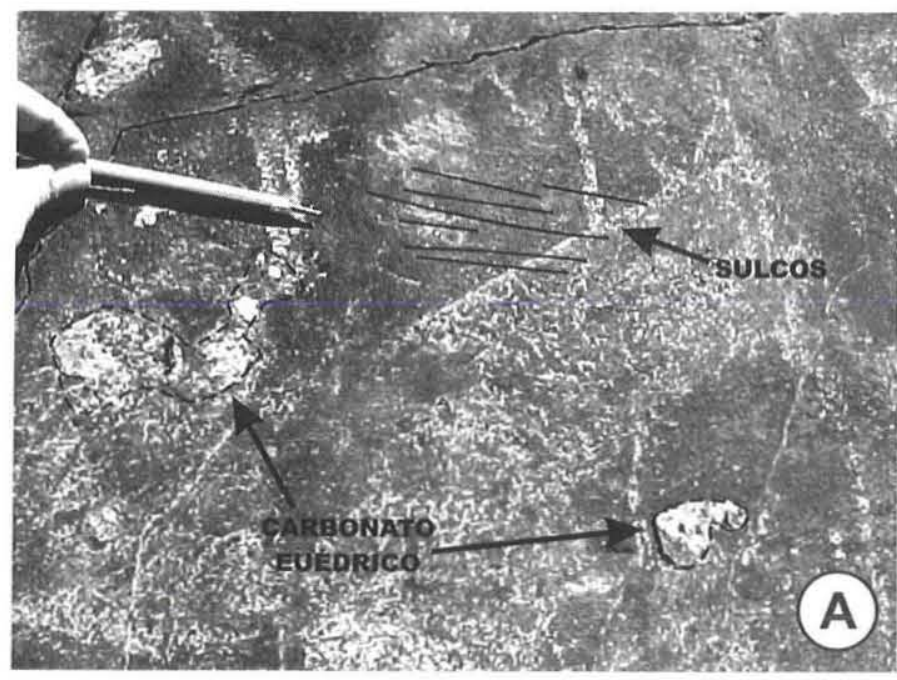

anastomosadas, com bandas dispersas ou concentrados em zonas de deslizamento (slip zones), algumas delas de dimensões métricas (Fig. 11 a). O diagrama da figura $1 \mathrm{lb}$ mostra que as falhas com bandas de deformação apresentam uma direção principal N45$60 \mathrm{~W}$ bastante consistente, além de máximos secundários a E-W e N60E. Estas direções são relacionadas ao principal evento de deformação registrado na área, que por sua vez aproveitou as descontinuidades pretéritas nas paredes dos diques. No leito do Rio Apucaraninha, junto à cachoeira e Usina Hidroelétrica (U.H. COPEL) homônimas (ponto 04 da fig. 7), ocorre um importante conjunto de bandas de deformação associadas a uma falha normal com componente sinistral (Fig. 11). Esta falha situa-se na borda da ZF Apucaraninha (Fig. 7), sendo que as bandas ocorrem relacionadas com ambos os componentes da falha - o caráter normal relaciona-se a falhas antitéticas (R') seccionadas por zonas de deslizamento (direção ' $Y$ ' - fig. 1 le), formando um sistema conjugado semelhante àquele descrito por Davis et al. (1999); - enquanto o caráter direciona,I sinistral, é indicado por feições sigmóides e padrão anastomosado P, R-Y (Fig. Ilc). Outros exemplos das propriedades geométricas das bandas de deformação são mostrados na figura 12 , onde prevalece a geometria anastomosada e a presença das bandas em planos de falhas direcionais e normais.

A densidade transversal das bandas relaciona-se quantitativamente ao tipo, rejeito e à distância do plano da falha à qual estão geneticamente relacionadas (Antonellini \& Aydin 1995, Davis et al. 1999, Shipton \& Cowie 2001). No afloramento ilustrado na figura 11 foi observada deformação progressiva relacionada ao muro da uma zona de falha normal-sinistral, onde a magnitude da deformação aumenta no sentido do plano principal mais deformado, que exibe feições relacionadas a zonas de deslizamento (slip zones). Da mesma forma, a ocorrência de bandas mais espaçadas e com menor espessura (e.g. fig. 12b) sugere que estas falhas sejam de pequena magnitude ou que estas bandas se encontram distantes do plano de uma falha importante. A geometria anastomosada das bandas de deformação contrasta com à das juntas e fotolineamentos, que em geral são planas e retilíneas. Esta

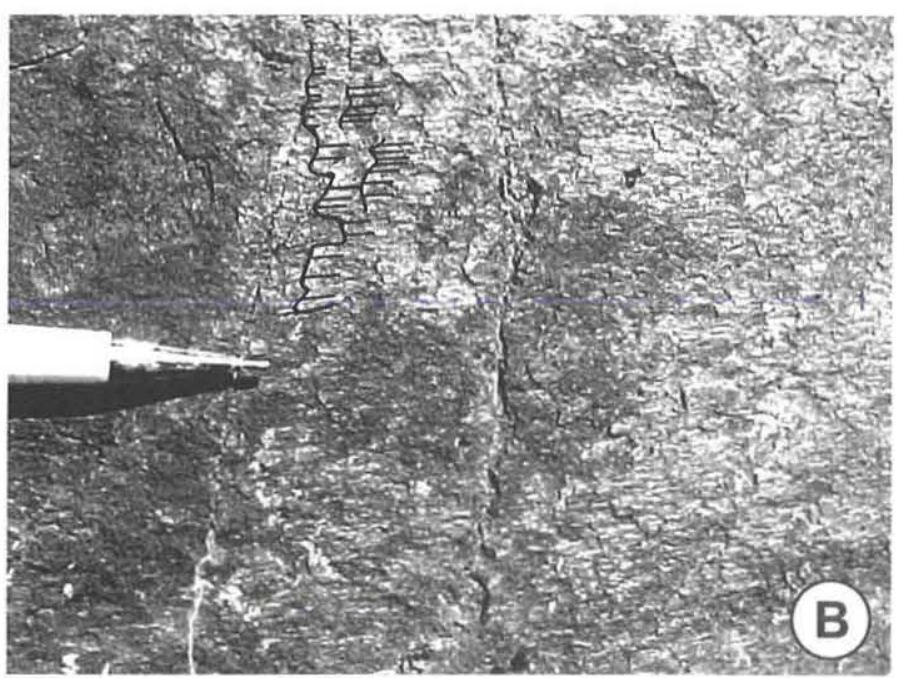

Figura 10 - Planos de falha de duas famílias no mesmo afloramento, onde: A) plano de falha (91/88) aberta, com sulcos e preenchida por carbonato euédrico; B) plano de falha cisalhante dextral (349/86) com estrias e ressaltos formadas em carbonato fibroso. 

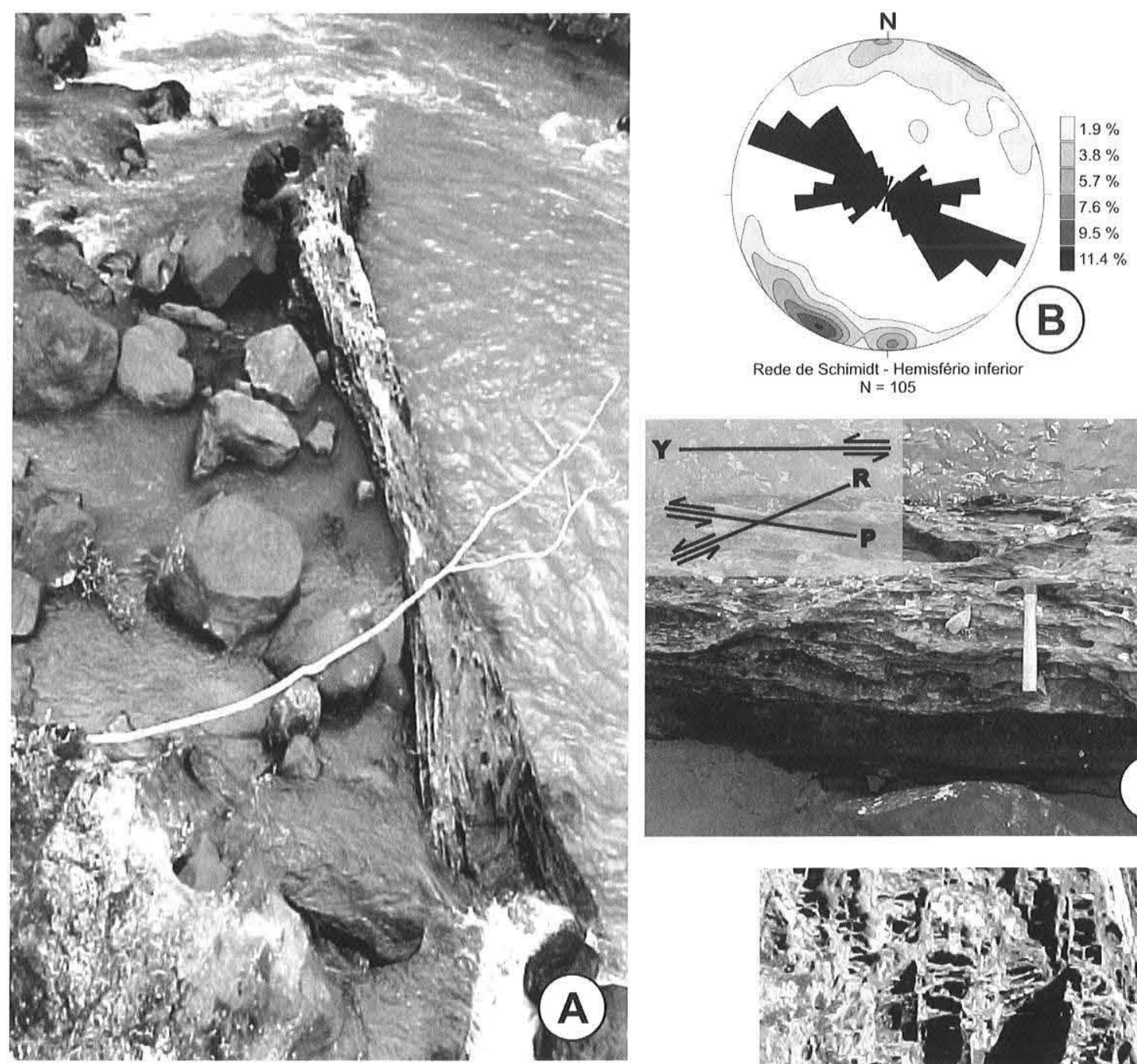

Rede de Schimidt - Hemisfério inferior
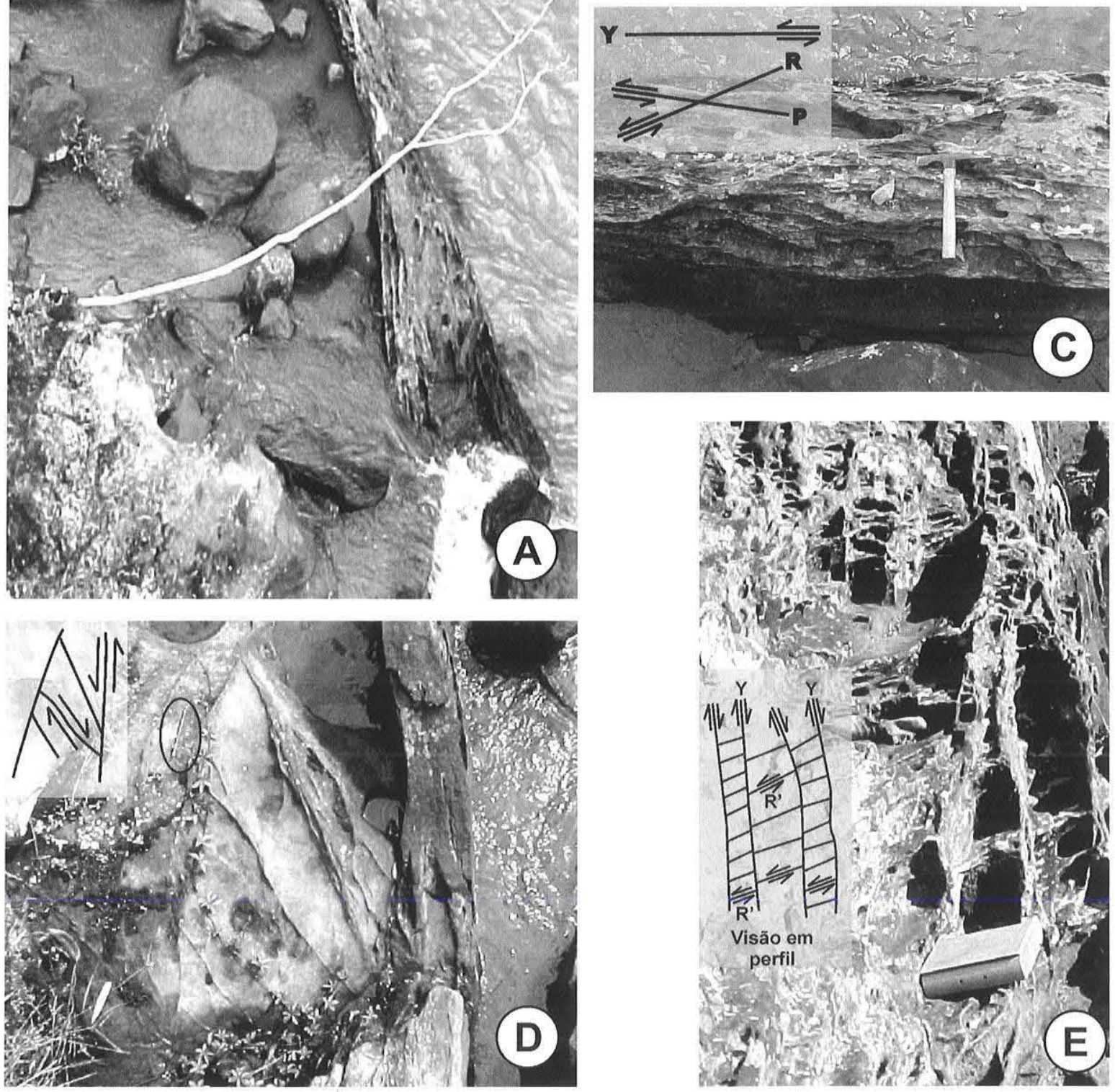

Figura II - Exemplos de bandas de deformação associadas a uma falha normal-sinistral de direção média N70W. que afloram no leito do Rio Apucaraninha junto a U.H. Apucaraninha (arenitos da Formação Pirambóia): A) Visão geral (bloco direito baixo); B) Diagrama sinóptico das falhas com bandas de deformação; C) Detalhe em planta da fotografia "a", onde estão interpretados os planos frente ao modelo de Riedel, considerando a falha Y a N7OW: D) Detalhe em planta de uma porção menos deformada, onde aparecem planos de falha de $2^{a}$ ordem entre planos da direção principal; E) Vista em perfil das bandas de deformação, onde se observa as direções " $Y$ " (sub vertical) e R' associadas à movimentação normal da falha. 
mesma relação entre bandas de deformação e juntas/ fotolineamentos foi verificada por Antonellini \& Aydin (1995), que ainda observaram feições denominadas estruturas em olho e rampa (eye and ramp structures). Estas estruturas e as bandas de deformação em geral, quando insuficientemente conectadas durante o movimento, não atuam como barreira efetiva ao fluxo, propriedade esta restrita às falhas de largura na ordem de dezenas de centímetros. Exemplos de falhas que atuam como barreiras são ilustradas nas figuras 11 e $12 \mathrm{a}$, que apresentam $5 \mathrm{~m}$ e $30 \mathrm{~cm}$ de zona deformada, respectivamente. Na falha da figura $12 \mathrm{~b}$ as bandas são estreitas e descontínuas, permitindo atualmente o fluxo de fluídos através da estrutura.

ANÁLISE CINEMÁTICA Mediante a integração dos diversos dados estruturais coletados e consultados, puderam-se caracteriZar os eventos de deformação que afetaram as rochas do Grupo São Bento após a colocação dos diques de diábasio, no Cretáceo Inferior, na região estudada (Fig. 13). A análise cinemática e denominações das direções de falhas (Y, R, P e R') foram baseadas no modelo de Riedel. Importante ressaltar que a presença de estruturas herdadas (diques de diábasio) nos arenitos e em alguns derrames pode afetar a relação angular entre as direções de fraturamento posteriormente geradas. Os diques foram encaixados num importante evento distensional com soerguimento regional e magmatismo eo-cretácico associado, que deram origem a um extenso enxame de diques praticamente retilíneos e verticais, exceto em algumas porções no eixo do arco onde feições sigmoidais e escalonadas indicam movimentos dextrais durante a colocação dos diques (Strugale 2002, Strugale et al. 2003).

Nas unidades arenosas, em especial na Formação Botucatu, foram caracterizados dois conjuntos principais de falhas, que formam um par conjugado - $\mathrm{O}$ primeiro conjunto é composto por falhas sinistrais de direção N35-65W e falhas normais N60-80W, além dos grandes fotolineamentos e diques herdados de direção N40-50W, estes considerados como a direção principal ou "Y" da área em razão de sua persistência. A contemporaneidade destes falhamentos é exemplificada na figura 11, onde feições relaciona- das às falhas normais e sinistrais se fazem presentes na geometria das bandas de deformação. As direções "P" e "R" têm direção média N35W e N65W e são compostas por falhas transcorrentes sinistrais e falhas normais e sinistrais respectivamente. O segundo conjunto de falhas transcorrentes tem movimento dextral e direção N50E, disposto na direção antitética (R') do par conjugado. A figura 14 mostra, no mesmo afloramento, falhas normais (217/80 - direção R) e dextrais (135/84 - direção R'). Entretanto os diques, na condição de estrutura herdada de alta continuidade $\mathrm{e}$ persistência, atuaram como planos de reativação que acomodaram parte dos esforços, fato corroborado pela quantidade e magnitude de fotoelementos com direção N40-65W.

O conjunto de falhas descrito acima, junto com uma falha inversa $\mathrm{N}$-S, caracteriza o primeiro evento deformacional, relacionado a um regime de esforços onde a direção de extensão horizontal máxima $\left(\mathrm{SH}_{\text {in }}\right.$ )é orientada segundo $\mathrm{N} 10 \mathrm{E}$. As falhas normais de direção N80W devem representar as fraturas "T" paralelas à direção de compressão horizontal máxima $\left(\mathrm{SH}_{\text {mix }}\right)$ orientada naquela direção. A presença em campo de elementos relacionados a falhas normais e sinistrais contemporâneas (Fig. I1), compreendidas entre as direções N35-80W da figura 13a, corrobora com um regime de esforços direcionais com componente normal. As direções de fraturas geradas neste evento são correlatas às direções principais dos fotolineamentos (Fig. 7).

Pela presença nos basaltos da Formação Serra Geral de algumas estruturas incompatíveis com a deformação impressa nos arenitos, pressupõem-se um segundo evento deformacional (Fig. 13b) bem marcado naquela unidade litoestratigráfica. Este evento foi caracterizado a partir de poucos indicadores cinemáticos descritos nos basaltos, exemplificados na figura 10 , onde há falhas dextrais ortogonais a fraturas abertas preenchidas por carbonato euédrico. Entretanto, existem ainda algumas falhas incompatíveis com os campos de esforços dos eventos propostos na figura 13 , tais como falhas sinistrais orientadas E-W nos arenitos (Fig. 9).

A presença de disjunções freqüentes e a ausência de diques na maioria dos derrames podem ter atuado no sentido de particionar as deformações, propagadas a partir dos arenitos com diques,
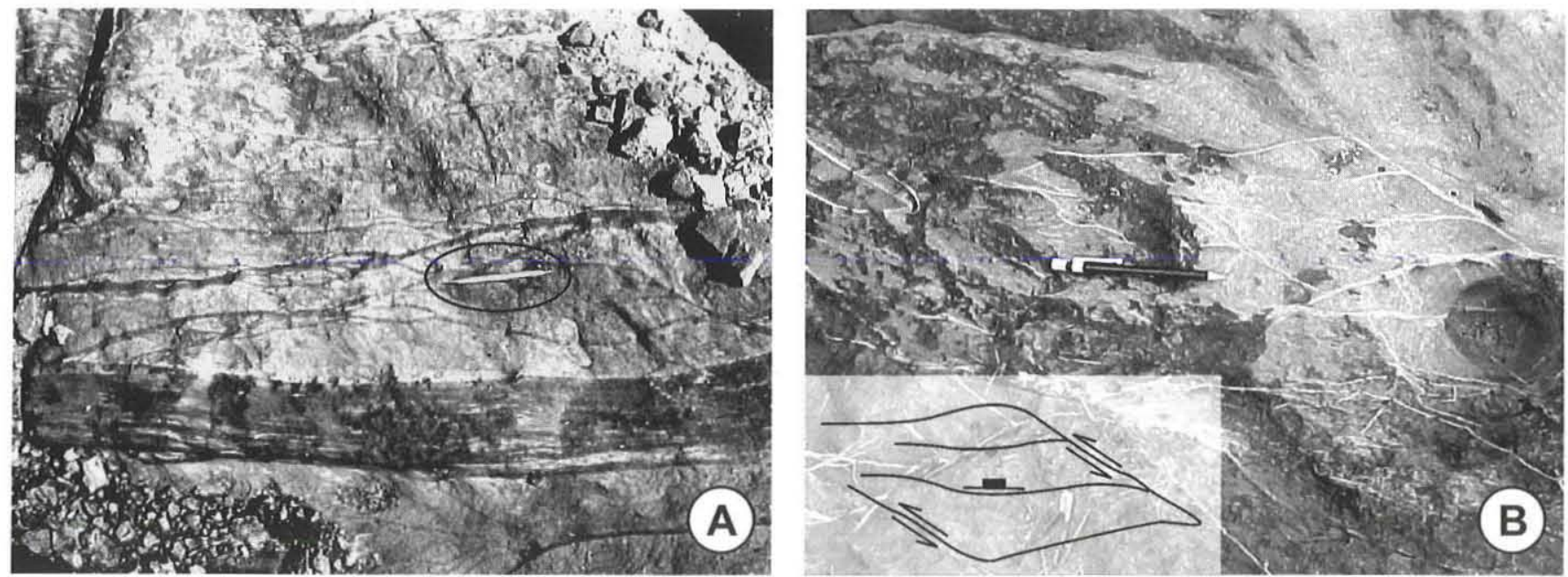

Figura 12 - Outros exemplos de bandas de deformação: A) Zona de falha (48/85) com bandas de deformação (Fácies Eólica; Formação Botucatu); B) Bandas de deformação milimétricas que indicam uma feição tipo pull-apart (Fácies Eólica, Formação Botuc(atu). 


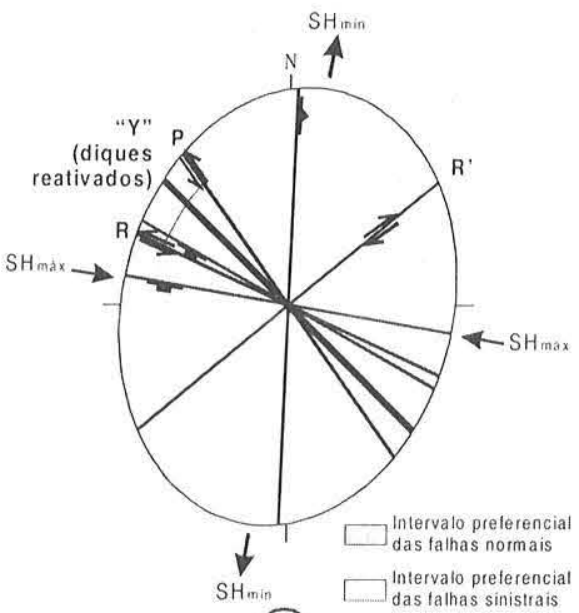

(A)

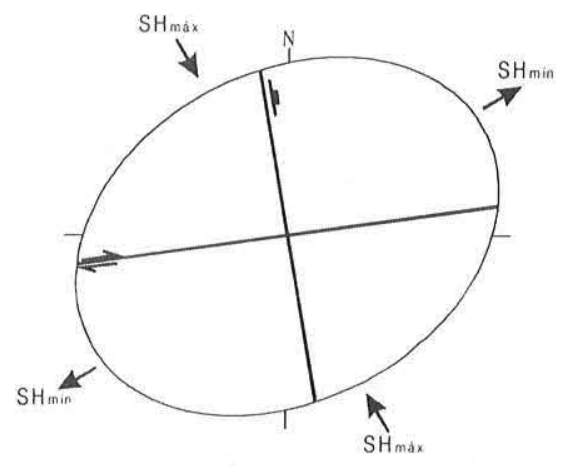

(B)

Figura 13 - Eventos deformacionais impressos nas rochas do Grupo São Bento na região de São Jerônimo da Serra, onde as falhas nos diagramas são as modas das falhas medidas em campo: A)EVENTO 1 - Neo-Cretáceo: apenas falhas nos arenitos; B) Evento 2 (provável) - Terciário: falhas observadas nos arenitos e rochas básicas.

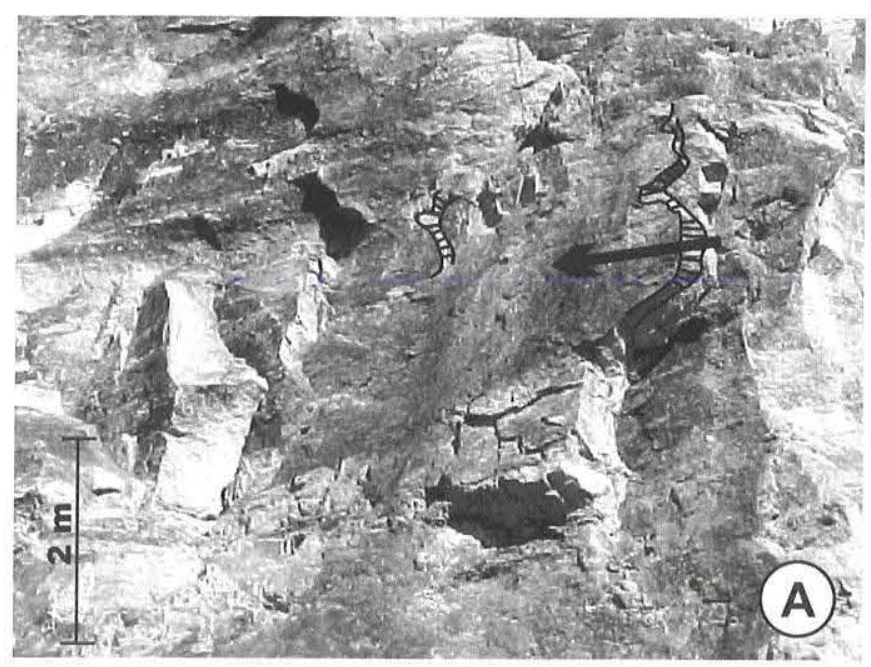

originando nos basaltos da Formação Serra Geral uma assinatura estrutural diferenciada em relação aos arenitos sotopostos. Tal premissa, aliada a pouca densidade de dados, não permite conclusões precisas; o segundo evento aqui designado e as demais estruturas incompatíveis podem fazer parte do Evento D2 descrito por Strugale (2002) e Strugale et cl. (2003) na região central do Arco de Ponta Grossa, o qual caracteriza-se por uma dispersão importante dos vetores de $\mathrm{SH}_{\text {mix }}$ em torno da direção E-W. Riccomini (1995) define dois eventos tectônicos que afetam os sedimentos neo-cretáceos da Bacia Bauru, onde o primeiro tem o eixo de tensão principal máxima $\left(\sigma_{1}\right)$ orientado em média a E-W e o segundo evento é relacionado a um $\sigma_{1}$ orientado $\mathrm{N}-\mathrm{S}$ em média. Na comparação os dados aqui obtidos, ambos os eventos da figura 13 assemelham-se com as deformações reconhecidas no Grupo Bauru ora citadas.

CONSIDERAÇÕES FINAIS A Formação Botucatuassenta-se em discordância angular: sobre cerca de $15 \mathrm{~m}$ de arenitos lamosos e friáveis da Formação Pirambóia, sendo constituída por arenitos vermelhos, quartzosos, divididos em Fácies Torrencial (sentido de Soares 1973) na base, com aproximadamente $20 \mathrm{~m}$ de espessura, compostos de arenitos grossos a conglomeráticos, e Eólica no topo (até $50 \mathrm{~m}$ de arenitos finos e bem selecionados). A Formação Serra Geral é composta por derrames de basaltos negros afaníticos e dacitos porfiríticos, além dos diversos corpos de intrusivas básicas correlatas, representados principalmente por diques.

O evento deformacional característico dos arenitos é representado por um par conjugado gerado sob regime transcorrente sinistral com componente normal ( $\mathrm{SH}_{\text {mix }}$ N80W-S10E), que gerou um importante conjunto de falhas normais e sinistrais de direções que variam a N35-80W (média N40-60W), intimamente associadas a bandas'e zonas de bandas de deformação de várias magnitudes (larguras milimétricas a decamétricas). Os diques de diabásio herdados encaixados nas falhas principais (N40-50W) atuaram no sentido de acomodar parte dos deslocamentos na forma de reativações. A reativação dos diques e a comparação com as deformações no Grupo Bauru (Cretáceo Superior) corrobora com uma idade Neo-Cretácea a Terciária. A segunda direção, conjugada,

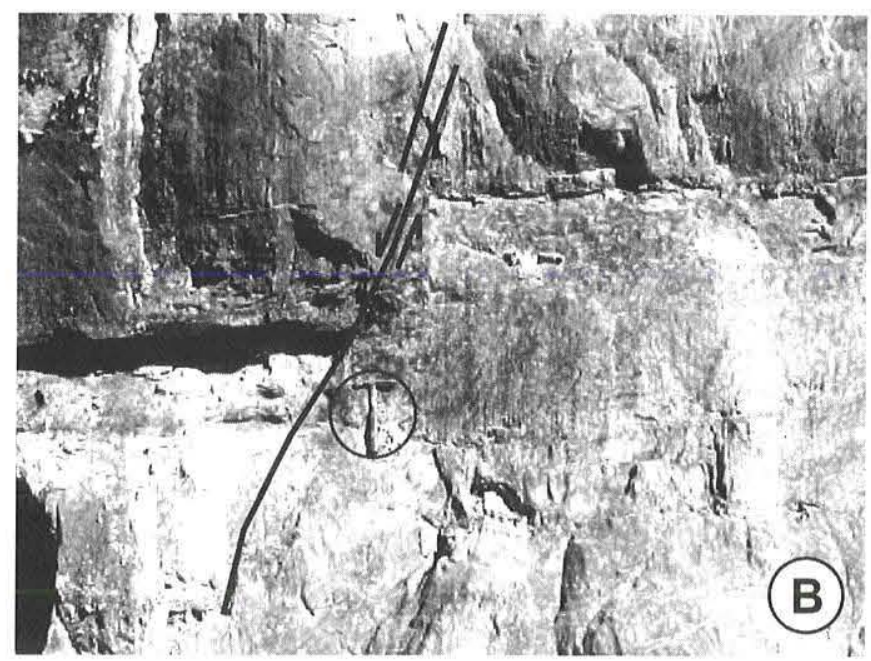

Figura 14 - Duas famílias de falhas em afloramento da Fácies Torrencial da Formação Botucatu, que configuram um par conjugado (periferia de São Jerônimo da Serra): A) fraturas escalonadas em plano 135/84 com sulcos subhorizontais que indicam movimento sinistral; B) falha normal (217/80). 
relacionada a este evento, consiste de falhas dextrais a N50E, algumas com bandas de deformação. Estas direções conjugadas correspondem às direções do par de fotolineamentos mais importantes (N40-50W e N40-60E).

Um segundo provável evento com poucos registros, restritos aos basaltos da Formação Serra Geral, afetou a região em estudo, relacionado a um tensor $\mathrm{SH}_{\text {min }}$ orientado segundo NE-SW a ENEWSW que pode explicar os fotolineamentos esparsos de direção E-W e N-S. Este evento tem uma imprecisa idade Terciária sugerida.

A influência na migração de HC é restrita ao intervalo de tempo em que os esforços do primeiro evento atuavam nos arenitosreservatório (Neo-Cretáceo), que coincide com uma importante época de geração e migração na Bacia do Paraná. Durante esse período, a migração deu-se preferencialmente pelas falhas N40$60 \mathrm{~W}$, onde o processo de cominuição nas falhas propiciou a formação de condutos preferenciais onde hoje observamos as bandas de deformação, junto às paredes dos principais diques. Entretanto, como as rochas arenosas são capeadas por derrames basálticos, não-selantes devido a extensiva presença de fraturamernto representados por disjunções colunares e fraturas tectônicas, é de se esperar que boa parte dos fluídos que passaram por estes condutos tenha atingido a superfície. Possíveis trapas podem ocorrer sob soleiras de diabásio dentro da seção arenosa, diques não-subverticais ou até mesmo sob derrames menos fraturados (e.g.: dacito porfirítico). Tal modelo de estruturação pode, entretanto, ser aplicado analogamente a reservatórios mais profundos, como as formações Rio Bonito (Grupo Passa Dois) e Campo Mourão (Permiano Inferior do Grupo Itararé).

Quanto a compartimentação estrutural do SAG, as falhas principais (N40-50W e N40-60), estas mais espaçadas) devem comportar-se como barreiras, de acordo com seu potencial selante em função das dimensões longitudinais e transversais destas (conforme o modelo de Antonellini \& Aydin 1995). Em primeiro lugar, a área de estudo situa-se na zona de recarga do SAG, devido a suas características altimétricas e ao mergulho regional das camadas. A compartimentação de 1" ordem apresenta geometria romboedral, balizada pelas direções principais N40-50W e N40-60E, ou mesmo retangular no interior das zonas de falhas N40-50W (e.g. ZF. Rio do Tigre). Considerando um mergulho regional para NW das camadas sedimentares da bacia, que representa o condicionante de maior magnitude à migração de água, a influência maior é dada pelas falhas-barreiras $\mathrm{N} 40-60 \mathrm{E}$, por se posicionarem perpendicularmente à direção do fluxo, criando compartimentos lateralmente limitados pelas falhas N40-60W, dentro dos quais a circulação da água será restringida. Ainda, em função do paralelismo das falhasbarreira principais (N40-50W) com a direção principal de fluxo condicionada pelo mergulho das camadas, são criados corredores de fluxo nas paredes destas estruturas tectônicas, onde a maior concentração do fluxo será dependente de variações locais no mergulho das camadas. Estas variações são controladas pela presença das zonas de falhas de direção N40-50W (e.g. ZF Rio do Tigre Fig. 5), que criam corredores de deformação onde as camadas lateralmente adjacentes possuem mergulhos divergentes para fora da estrutura.

A primeira ordem de compartimentação pode ser modificada em locais onde houver uma segmentação destas estruturas (NW$\mathrm{NE}$ ) por uma movimentação posterior das falhas E-W e N-S relacionadas ao segundo evento. Provavelmente durante o segundo evento, as falhas de abertura N-S devem comportar-se como condutos, os quais podem localmente conectar os compartimentos criados pelo primeiro evento.

Agradecimentos Ao CNPq (processo 463(0)2/()()-8), FINEP e PETROBRAS pelo apoio financeiro; e à UFPR pelo apoio institucional. Aos Profs. Augustinho Rigoti, Ernani F. da Rosa Filho e Francisco J. F. Ferreira (DEGEOL - UFPR) pelas sugestões e críticas. Michael Strugale agradece a concessão de bolsa de mestrado pela CAPES. Sidnei Pires Rostirolla agradece a concessão de bolsa de produtividade em pesquisa do CNPq. Aos revisores da RBG pelas sugestões ao manuscrito.

\section{Referências}

Antonellini M. \& Aydin A. 1995. Effect of faulting on fluid flow in porous sandstones: geometry and spacial distribution. $A A P G$ Bulletin, 79:642-671.

Araújo L.M., França A.B., Potter P.E. 1995. Aquíífero gigante do Mercosul no Brasil, Argentina, Paraguai e Uruguai: Mapas Hidrogeológicos das Formações Botucatu, Buena Vista, Misiones e Tacuarembó. UFPR/Petrobras, 16 p., 9 mapas.

Caetano-Chang M.R. 1993. Estado d'arte do conhecimentos sedimentológicos/estratigráficos das formações Pirambóia e Botucatu no Estado de São Paulo. In: UNESP, Simp. Cronoestratigrafia da Bacia do Paraná, 1, Resumos. 84-85.

Davis G.H., Bump A.P., García P.E., Ahlgren S.G. 1999. Conjugate Riedel deformation band shear zones. J. Struct. Geol., 22:169-190.

Fernandes L.A. \& Coimbra A.M. 2000. Revisão estratigráfica da parte oriental da Bacia Bauru (Neocretáceo). Rev. Bras. Geoc., 30:717728.

Ferreira F.J.F. 1982. Integração de dados aeromagnéticos e geológicos: configuração e evolução tectônica do Arco de Ponta Grossà. Dissertação de Mestrado, Instituto de Geociências, Universidade de São Paulo, 170p.

França A.B. \& Potter P.E. 1988. Estratigrafia, ambiente deposicional e análise de reservatórios do Grupo Itararé (Permocarbonífero), Bacia do Paraná (Parte 1). Boletim de Geociências da Petrobrás, 2:147 191.

Maack R. 1981. Geografia física do Estado do Paraná. 2" ed. José Olympio Ed., Rio de Janeiro, 450pp.

Magnavita L.P. 2000. Deformation mechanics in porous sandstones: implications for development of fault seal and migration paths in the Recôncavo Basin, Brazil. In. M.R. Melo \& B.J. Kratz (eds.) Petroleum Systems of South Atlantic Margins, 73, AAPG Memoir, pp: $195-212$.

Marini O. J., Fuck R. A., Trein E. 1967. O Grupo Açungui no Estado do Paraná. Bol. Paranaense de Geociências, 23/25:52-105.

Milani E. J., França A.B., Schneider R.L. 1994. Bacia do Paraná. Boletimı 
de Geociências da Petrobrás, 8-1:69-82.

Riccomini C. 1995. Tectonismo gerador e deformador dos depósitos sedimentares pós-gondvânicos da porção centro-oriental do Estado de São Paulo e áreas rizinhas. Tese de Livre-Docência, Instituto de Geociências, Universidade de São Paulo, 100p.

Shipton Z.K. \& Cowie P.A. 2001. Damage zone and slip-surface evolution over ? $\mathrm{m}$ up to $\mathrm{km}$ scales in high-porosity Navajo sandstone, Utah. J. struc. Geol., 23:1825-1844.

Soares P.C. 1973. O Mesozóico gonduânico no Estado de São Paulo. Tese de Doutoramento, Faculdade de Filosofia, Ciências e Letras, Universidade Estadual Paulista, 152p.

Soares P.C. 1975. Divisão Estratigráfica do Mesozóico no Estado de São Paulo. Rei: Bras. Geoc., 5:229-251.

Soares P.C.. Barcellos P.E., Csordas S.M. 1982. Lineamentos em imagens Landsat e Radar e suas implicações no conhecimento tectônico da Bacia do Paraná. In: INPE/CNPq, Simp. Bras. Sensoriamento Remoto, 2, Anciis, p. 143-167.

Strugale M. 2002. Arcabouço e evolução estrutural do Arco de Ponta
Grossa no Grupo São Bento (Mesozóico): implicações na hidrodinâmica do sistema aquïfero Guarani e na migração de hidrocarbonetos na Bacia do Paraná. Dissertação de Mestrado. Departamento de Geologia, Universidade Federal do Paraná, 138p.

Strugale M., Rostirolla S.P., Mancini F., Trzaskos-Lipski B., Figueira I.F.R.. Freitas R.C. 2003 Evolução estrutural do Arco de Ponta Grossa no Cretáceo a partir da análise de estruturas rúpteis no Grupo São Bento (Bacia do Paraná). In: SBG, SNET, 9. Boletim de Resumos, p. 320-323.

Vieira A.J. 1973. Geologia do centro e nordeste do Paraná e centro-sul de São Paulo. In. SBG - Congr. Bras. Geol., 28, Anais, p. 259-277.

Zalán P.V., Wolff S., Appi V.T., Zanotto O.A. 1987. Tectônica e Sedimentação da Bacia do Paraná. In. SBG, Simp. Sul-brasileiro Geol., 3, Anciis, p. 44I-474.

Manuscrito A-1351

Recebido em 20 de junho de 2002

Revisão dos autores em 20 de abril de 2004 Revisão aceita em 10 de maio de 2004 